\title{
Reservoir Yield Analysis Using Multiple Variable Regression Screening Model and Its Comparison: A Study of 28 Water Supply Dams in Malaysia
}

${ }^{1}$ Hock-Hwee Heng ${ }^{*},{ }^{1}$ Ching-Poon Hii, ${ }^{2}$ Fei-Lu Siaw, ${ }^{2}$ Wang-Fook Pan

${ }^{1}$ Jurutera Adda Sdn Bhd

${ }^{2}$ Faculty of Engineering and the Built Environment, SEGi University

henghhwee@gmail.com

\begin{abstract}
This paper presents the study of water supply dams in Malaysia using the Storage Yield Reliability (SYR) model. The model is a linearized regressed equation with five independent variables comprising of hydrological and physical properties of the reservoir system, namely dam inflows and its statistical moment properties, reservoir storage capacity, and designated return periods or probability of non-exceedance of low flow. A total of twenty eight water supply reservoir schemes were selected for comparison in this study. Seventeen and eleven reservoirs respectively operated under direct supply (DS) and regulating reservoir (RR) modes. The estimated SYR yields were compared to the known water treatment plant (WTP) capacities of these reservoir schemes. Out of five variables, catchment area (indirectly proportionate to dam inflows) and storage capacity are positively correlated to the estimated SYR yields. The SYR model adopted in this study could provide quick yield assessment for all the twenty eight DS and RR reservoir schemes in Malaysia. In summary, the multivariate regression model SYR approach can be used as the first screening process of DS and RR operation mode reservoir yield estimation in Malaysia.
\end{abstract}

Keywords: reservoir, yield, water supply, storage facility, hydropower 


\begin{tabular}{|c|c|c|c|}
\hline A & Catchment area & ORS & Off river storage \\
\hline AAF & Annual average flow & PMP/PMF & $\begin{array}{c}\text { Probable maximum } \\
\text { precipitation/flood }\end{array}$ \\
\hline BA & Behavior analysis & PR & percentage of regulation \\
\hline DS & Direct supply & PS & Pump storage \\
\hline DSA & $\begin{array}{c}\text { Drought sequence } \\
\text { analysis }\end{array}$ & PUB & Public Utility Board \\
\hline ECL & $\begin{array}{c}\text { Embankment crest } \\
\text { level }\end{array}$ & RCC & Roll compacted concrete \\
\hline FELDA & $\begin{array}{c}\text { Federal Land } \\
\text { Development } \\
\text { Authority }\end{array}$ & ROF & Run of river \\
\hline FSL & Full supply level & ROR & Run of river \\
\hline JPS & $\begin{array}{c}\text { Jabatan Pengairan dan } \\
\text { Saliran }\end{array}$ & SAJ & Syarikat Air Johor \\
\hline JRWW & $\begin{array}{c}\text { Johor River Water } \\
\text { Works }\end{array}$ & SPA & Sequential peak analysis \\
\hline LSD & Land survey datum & SYR & Storage yield reliability \\
\hline MADA & $\begin{array}{c}\text { Muda Agricultural } \\
\text { Development } \\
\text { Authority }\end{array}$ & TIDEDA & Time dependent database \\
system
\end{tabular}

\section{List of Symbols and Abbreviations}

\section{Introduction}

Provision of storage facility (in the form of reservoir and storage embankment) is a vital option and a necessity in water resource management to buffer the spatiality and temporality of hydrological distribution. In the event of prevailing low flow regime, the water stored in the reservoir could be used to augment supply when raw water deficit occurs at the water intakes. It is an effective and efficient solution when potable water demand is outpacing raw water supply by direct abstraction from natural flows in rivers or lakes.

There are 65 existing water supply dams serving primarily as raw water sources to the respective water treatment plants (WTPs). Out of these, 29 schemes operate under pump storage (PS) mode, where the reservoir storages 
are augmented by either inter basin or downstream raw water catchment. The remaining 36 schemes are operated based on direct supply (DS) or regulating reservoir (RR) mode. The storage capacity of these water supply schemes range from less than $1 \mathrm{MCM}$ to approximately $370 \mathrm{MCM}$.

The drawback of DS scheme is its limitation in harnessing high reliable yield. This is primarily due to catchment areas that are physically smaller in dimension. The operation of DS reservoirs is constrained by the amount of water that the reservoir storage can capture by its natural catchment area. Most of these DS reservoirs are located near the river basin. Raw water is directly piped to the respective WTPs. The water quality appears to be clean and mostly satisfying the raw water quality standard and criteria. On the other hand, reservoirs that operate under RR mode could increase the relative yield significantly by taking advantage of bigger catchment area that draw raw waters at a downstream intake. The dam only plays its role in occasional augmentation by releasing flow on demand, in the case of deficit forecast at the downstream intake.

In Malaysia, these existing reservoir schemes for the purpose of providing domestic water supply are mainly run on these two DS and RR operational modes. However, over the years due to increasing demand and disparity in spatial and temporal distribution of rainfall and flow regime, option is limited to provision of increasing the storage capacity by either commissioning a new dam or retrofitting the existing scheme by dam raising and concurrently switching the mode of operation, i.e. from DS or RR mode to PS scheme. The PS mode of operation offers various advantages such as by deferring the commissioning of a new dam scheme and the process of retrofitting only involves the existing structure of the dam and its associated appurtenances. The momentum and zeal of new dam building endeavor for the benefit of economic development is now being slowed down mainly due to a host of challenging adverse environmental as well as social issues. These associated issues concerning dam building are to be first tackled before any instream river obstructing structure can be built. The consultative efforts involving various 
stakeholders are always effectively inclusive, and this makes the decisionmaking process rather tedious and difficult. Moreover, the current legislation and rising environmental awareness have effectively impeded the water resources planning and design processes with dam/reservoir storage options. In addition to this, selection of suitable dam sites even mostly in the headwater region of a remote river basin are challenging due to human settlement and encroachment into the once sparsely populated mountainous and hilly upland. Therefore prior to the decision on switching the crucial role of the dam operation by a retrofitting exercise, it is important to be able to estimate the existing reliable yield that can be harnessed for cost benefit comparison purpose.

\subsection{Problem Statement}

The estimation of reliable yield which is defined as a constant supply of raw water under a specific probability of nonoccurrence of flow or commonly known as return period. Conventional behavioral analysis (BA) is routinely carried out to estimate the magnitude of reliable sources of raw water that could be harnessed by the reservoir schemes. This is essentially a water balance and conservation approach by taking into account the interplay amongst the inflow (by river inflow and rainfall over the reservoir surface) and outflow (draft rate or yield, prior releases, and evaporation over the surface of reservoir water body). The deficit or surplus is then related to both the inflow and outflow pattern and are taken into account in the rise and fall of the reservoir storage.

The conventional approach of yield estimation is technically tedious, data intensive, and time consuming. An alternative broad and macroscopic way of providing a firsthand approach of reservoir yield estimation is by means of global screening techniques. These techniques are simple and straightforward and most of them require relatively fewer parameters for computation. They are therefore considered as a convenient approach to provide a first time approach in yield estimation vis-à-vis a detailed and time consuming undertaking. 


\subsection{Objectives}

The primary objective of this study is to investigate a new reliable yield technique for the existing reservoir schemes. The storage-yield-reliability (SYR) model (Kuria and Vogel 2014) was applied to some selected 28 existing reservoir schemes of either DS or RR operating mode. The results of this undertaking were subsequently compared either with the known yield (inclusive of compensation flow past the dam or intake structure, if any) or intake capacity of the water supply scheme. This exercise excludes mostly the water supply PS scheme as the SYR model (Kuria and Vogel, 2014) appears to be more unsuitable with additional variables such as transfer rate of additional waters to the reservoir. In addition, smaller scale water supply dam scheme where pertinent model input information are difficult to obtain is also excluded from this Study. Majority of the 28 existing water supply reservoir schemes are located in Peninsular Malaysia. Out of these, only 4 schemes are located in Sarawak.

\section{Materials and Methods}

The hydrological design standard for water supply system in Malaysia is based on the selection of the most severe observed streamflow records, preferably of more than 30 years of length by rule of thumb. However even this minimum length of database could not be possible due to a lack of gauging station network not only in the project area but over the entire country. To overcome this weakness in data availability as well as the length of records in the earlier years of hydrological design, a stack drought sequence time series is devised with the purpose to derive the representative low flow series of a given probability of occurrence or commonly known as return period. This technique is popularly known as Twort drought sequence approach (DSA) in Malaysia (Brandt et al, 2016).

\subsection{Drought Sequence Analysis}

The core principle of the low flow sequence is based on the unavailability of long-term observed hydrometric records in Malaysia. Due to limited length of records, this study infers a low flow scenario of a specific return period or 
probability of low flow occurrence. This leads to a representative drought flow series that could be adopted for water resource analysis for reservoir design and planning. By doing so, it is also implicitly assumed that this low flow series, commonly known as drought sequence approach (DSA) is representative of a design drought for reservoir yield estimation. In essence, it is an input to estimate the reliable yield of a reservoir system by using a simple and straightforward water balance calculation and/or sequential peak analysis (SPA). The deficit or surplus at the end of the time step can then be readily translated into either the reservoir drawdown or spillover at the dam crest.

By convention, the reliable yield should be reviewed using the latest hydrometric information. In the context of this study, the reliable yield shall be denoted as "continuous water supply and availability for a given probability of occurrence and/or reliability." (Brandt et al, 2016; Johnson et al., 2009). This continuity on raw water supply availability throughout the design specified drought period (normally 1:50-year drought or 2\% drought) is normally adopted in Malaysia. On the other hand, in the case of run-of-river yield without any significant or zero storage capacity, the design reliability of the water resources availability is also based on a 1:50-year return period but for various average-day durations, such as 7-, 14-, and 30-day.

For clarification, gross yield is defined as the total constant reservoir supply of water for the design specified drought periods, whereas, net yield is a continuous supply of raw water that could be obtained after subtracting prior compensation releases at the intakes or dams, irrigation allocations and environmental flow requirements.

\subsection{Long-Term Time Series}

The next stage of complementary assignment is to compare the results using a long-term water balance calculation approach. This long-term time series exercise has the advantage of relatively long term inflow, where longer period of observed records are most likely to include the worst low flow periods in the river basin. As a rule of thumb, a time series of more than 30 year or so observed records of streamflow stations is required in order to 
extrapolate a 1:50-year event. The method of water balance calculation is similar to the DSA approach but with a much longer inflow records compared to a shorter 36-month duration for DSA synthetic series (McMahon and Mein, 1986; Nagy et al, 2002).

In short, these two yield estimation techniques basically complement each other albeit using different length of records and interpretation. The differences in estimate yield using the two respective yield estimation techniques appear to be small and were mostly confined within the same order of magnitude. Nowadays although with a much longer length of essential hydrometric records of more than 50 years or so, it is nevertheless the trend that both techniques are being commonly adopted in the water resources planning in Malaysia. This technique of utilizing long-term observed hydrometric records which was introduced in McMahon and Mein (1986), Nagy et al. (2002), McMahon and Adeloye (2005), WMO (2008a, 2008b) is mostly practiced in the USA and Australia. These two different modes of assessment or technique is comparable at least on the same order of magnitude in terms of reliable yield concerned. Experiences in water supply dams in Malaysia occasionally reported slightly higher yield could be harnessed using long-term water balance technique.

One of the primary differences between DSA and long-term approaches is their respective definition and underlying quantitative meaning in interoperating the yield results. Both techniques however undoubtedly seek to draw the reservoir level down to its bottom of the live storage while leaving the dead storage capacity untouched (these are normally presented in the reservoir drawdown curves for various design and operational scenarios). In the DSA analysis, synthetic low flow series that represents a specific return period is prepared a priori. A $98 \%$ reliability criterion is mostly adopted for water supply project undertakings. In this technique, water balance calculation requires fairly long hydrometric records. Shorter records which do not include the known low flow episode nevertheless would skew the results of the yield estimation. 
Experiences in Malaysia showed that a slightly higher yield could be harnessed using this long-term time series flow records vis-à-vis a conventional DSA approach. However, it must be also be borne in mind that these two methodologies in yield estimation are essentially different in the context of yield definition. For yield calculation using long-term time series water balance basis, the reliable yield is likely to be overestimated if the hydrometric database is short. This essentially means that the most known critical drought as a result of low flow regime in the river basin is not been fully taken into consideration.

\subsection{Screening Techniques}

Other screening techniques which are suitable for preliminary assessment of the reservoir yield were presented in Gould-Dincer model (McMahon et al, 2007), Kuria and Vogel (2014) and others. These techniques provide first hand screening tool in light of the data shortage and other pertinent hydrometric information. These techniques are fairly suitable and deemed useful for a limited case of single reservoir configuration and a firsthand estimation of both storage capacity requirement and critical period. Furthermore the impact of climate change could also be included in the SYR model (McMahon et al, 2007).

A global data set consisting 729 unregulated river flows of at least 25year of records was collated to derive a SYR water yield climate change assessment model. This SYR model is basically a statistical linearized multiregression model using essential variables, such as inflow statistics, storage capacity, and probability of nonoccurrence or return period (Kuria and Vogel, 2014). The set of database adopted by Kuria and Vogel (2014) was similar to McMahon et al. (2007). Using the same technique, the yield pattern or BA was then carried out for the purpose to correlate the hydrological and physical variables of the dam/reservoir scheme mainly for water supply purpose. The reliability criteria considered were for $90 \%, 95 \%$, and $98 \%$. As a result, a total of 12,413 cases were simulated for the development of an empirical multiregression SYR model. The independent variables were the live storage, 
inflow statistics of mean, standard deviation, and skewness coefficient of the unregulated flows, and the return periods in the forms of normal standard score.

\section{Past Studies}

A recent study on six reservoir systems in Selangor using SYR model by Kuria and Vogel (2014) was undertaken by Heng et al (2017b). The paper presented a review of water supply yields for six reservoir schemes in both Selangor and Kuala Lumpur. The study was carried out using hydrometric database updated in 2009. Three approaches were used for yield calculations, namely Drought Sequence approach, Long-term time series, and SYR model Kuria and Vogel (2014) techniques/methodologies. The estimated gross yields of various reservoir schemes using the three techniques were consistent with only a variation of less than $5 \%$ (with the exception of Semenyih reservoir scheme),

\subsection{Yield Definition}

To avoid ambiguity on the interpretation of yield results, "yield" is defined as the steady supply of raw water that is: withdrawn, or/and diverted, or/and abstracted directly from rivers/lakes without the provision of some forms of storage facility, or commonly known as run-of-river yield. Raw water supply is extracted directly from the reservoir and in turn delivered to the targeted destination by a long-haul pipeline system in the case of a direct supply reservoir system, and/or diverted by pumping at the intakes further downstream. In case of shortfall, the remaining raw water sources are timely augmented by the reservoir releases, mostly in the upper catchment of the intake location. In this case, it is known as a regulating reservoir system.

A special case of PS reservoir, also known as off-river storage (ORS) scheme can be modified as a conventional reservoir system primarily for yield enhancement and flexibility in operation. Theoretically with dam raising, by increasing its storage capacity and at the same time, taking into advantages of spatiality and temporality of high flow regime in a river basin especially during prevailing monsoon months, these excess runoffs can be transferred via pump to refill the reservoir storage prior to the next drawdown/releasing 
phase. This essentially utilizes and captures the excess runoff that will otherwise go to waste. This option appears to be socially acceptable in lieu of planning of a new dam/reservoir scheme that has been difficult in the midst of active environmental advocacy. New dam/reservoir constructions have attracted mostly adverse responses and negative publicity in recent decades.

This continuous supply of raw water to the WTPs for the duration of the design specified drought period is commonly set at 1:50-year drought or $2 \%$ drought in Malaysia. In the case of run-of-river yield without much significant in-bank storage behind an intake structure, the reliability of the water resources is mostly based on 1:50-year return period and concurrently for various average-day durations, such as 1-, 7-, 14-, and 30-day.

In the lexicon of water supply industry convention of Malaysia, a "7Q50" criteria for run-of-river water supply abstraction is normally imposed. This denotes as a seven- (7-) day duration average low flow of a 1:50-year return period or probability of occurrence of low flow of equal or less than this magnitude. This uninterrupted raw water supply that could be maintained throughout the design drought period i.e. 1:50-year drought or $2 \%$ drought that is normally adopted in Malaysia.

Extra cautionary measure is also incorporated in the design criteria for both DS and RR scheme. The primary purpose of this criterion is to ensure timely refilling of the reservoir after a continuous period of drawdown during a prolonged dry period. Normally for the tropical climatic and hydrological characteristics of Malaysia, a 36-month carryover period is specified in tandem with the 1:50-year return period criteria. However, depending on the prevailing circumstances a slight extension of more than 36 month is possible.

The carryover period (also commonly known as critical period) is defined in the context of this study as the period, either daily or monthly, firstly by depleting the reservoir storage from its full level to empty (to the top of the dead storage level). Starting from this point, the reservoir enters into the refilling phase, and this phase ends when the full supply level of the reservoir is achieved. This unique "full-empty-full" carryover period of 36-month 
duration is imposed arbitrarily by management decision so that to ensure the reservoir storage will be refilled after an earlier depletion and continued drawdown period of 1:50-year severity. This assuages most of the negative perspectives and opinions of the public interest groups that typically oppose any form of dam and reservoir schemes in Malaysia. A longer period of refilling is therefore undesirable as this signifies over optimism on the reliable yield that could be harnessed during a drought period of certain significant severity without considering other social impacts. In Malaysia, an arbitrary of 36 months is imposed as an unwritten rule of standard reservoir design procedure. However, depending on the location of the reservoir scheme, some tolerance and relaxation by extending the carryover period could be made as per discretion of the designers. If the carryover period is extended beyond 36 months, this essentially means a less stringent rule and relaxation on the criteria of the yield and storage capacity of the reservoir scheme. Correspondingly by doing so, a higher yield can be harnessed if the rule on carryover period is further relaxed.

\section{Methodology of Assessment}

Kuria and Vogel (2014) require both physical dam/reservoir and hydrologic inflow parameters in the regression equation. The statistical parameters of inflow required are the mean, standard deviation, and skewness. These inflows parameters are mostly based on the long-term streamflow station records in Drainage and Irrigation Department (JPS) TIDEDA and HYDRA database system. Oftentimes, as there is no convenient hydrometric station located nearby the existing dam/reservoir site, hydrometric information is obtained from the nearest neighbouring streamflow stations in the vicinity (preferably within the same river basin and hydrological similar zone). This appears to be reasonable as the geographic regions more-or-less map well with the homogeneous hydrological zone. The prevailing weather pattern of Peninsular is influenced predominantly by two prevailing monsoon system that bring significant rainfalls to both Peninsular Malaysia, southwest 
monsoon from April to June and Northeast November to January of the following year.

Another significant physical variable that influences the magnitude of yield is the size of reservoir storage capacity. This is assumed to be the available live storage volume after appropriating a small adjustment or deduction for dead storage volume, which could range from as low as $5 \%$ to as high as $20 \%$ of the total storage volume. These hydrological inflow information and their physical dam parameters are tabulated in Table $\mathbf{1 .}$

Table 1. Reservoir and Dam Information

\begin{tabular}{|c|c|c|c|c|c|c|c|c|}
\hline & Dam & $\begin{array}{l}\text { Mod } \\
\text { e }\end{array}$ & $\begin{array}{r}\text { Catchme } \\
\text { nt } \\
\end{array}$ & $\begin{array}{r}\mathbf{A A} \\
\mathbf{F} \\
\end{array}$ & SS & $\begin{array}{r}\text { SKE } \\
\text { W } \\
\end{array}$ & $\begin{array}{r}\text { Storag } \\
\mathrm{e}\end{array}$ & $\begin{array}{r}\text { WT } \\
\text { P }\end{array}$ \\
\hline & & & $\mathrm{km}^{2}$ & $\begin{array}{l}\mathrm{mm} / \\
\text { year }\end{array}$ & $\begin{array}{r}\mathrm{mm} \\
/ \\
\text { yea } \\
\mathrm{r}\end{array}$ & nd & MCM & Mld \\
\hline & PERAK & & & & & & & \\
\hline 1 & Kinta & DS & 146 & 836 & 175 & 0.2 & 30.0 & 363 \\
\hline \multirow[t]{2}{*}{2} & Air Kuning & DS & 16 & $\begin{array}{r}145 \\
8\end{array}$ & 437 & 0.1 & 1.8 & 25 \\
\hline & $\begin{array}{l}\text { SELANGO } \\
\mathbf{R}\end{array}$ & & & & & & & \\
\hline 3 & $\begin{array}{l}\text { Selangor/ } \\
\text { Tinggi }\end{array}$ & RR & 1554 & $\begin{array}{r}129 \\
4 \\
\end{array}$ & 264 & 0.3 & 230.0 & 3000 \\
\hline 4 & Langat & RR & 254 & $\begin{array}{r}137 \\
6\end{array}$ & 307 & 0.5 & 34.1 & 544 \\
\hline 5 & Semenyih & RR & 571 & $\begin{array}{r}125 \\
3 \\
\end{array}$ & 282 & 0.5 & 60.4 & 751 \\
\hline 6 & Klang Gates & DS & 77 & $\begin{array}{r}108 \\
4\end{array}$ & 285 & 0.9 & 19.3 & 145 \\
\hline 7 & Batu & DS & 50 & $\begin{array}{r}123 \\
0\end{array}$ & 292 & 0.2 & 27.5 & 115 \\
\hline \multirow[t]{2}{*}{8} & $\begin{array}{l}\text { Subang } \\
\text { Lake Meru }\end{array}$ & DS & 10.3 & $\begin{array}{r}123 \\
3 \\
\end{array}$ & 290 & 0.1 & 3.5 & 23 \\
\hline & $\begin{array}{l}\text { NEGERI } \\
\text { SEMBILA } \\
\mathbf{N} \\
\end{array}$ & & & & & & & \\
\hline 9 & Teriang & RR & 796 & 650 & 143 & 0.0 & 50.0 & 500 \\
\hline $\begin{array}{l}1 \\
0\end{array}$ & $\begin{array}{l}\text { Batu } \\
\text { Hampar }\end{array}$ & RR & 222 & 979 & 283 & 0.0 & 3.0 & 222 \\
\hline $\begin{array}{l}1 \\
1 \\
\end{array}$ & Talang & RR & 1114 & 576 & 276 & 1.6 & 37.0 & 500 \\
\hline $\begin{array}{l}1 \\
2\end{array}$ & Gemencheh & DS & 35 & 388 & 284 & 1.5 & 30.0 & 45 \\
\hline & JOHOR & & & & & & & \\
\hline
\end{tabular}




\begin{tabular}{|c|c|c|c|c|c|c|c|c|}
\hline $\begin{array}{l}1 \\
3\end{array}$ & Bekok & DS & 350 & 789 & 378 & 1.2 & 24.0 & 210 \\
\hline $\begin{array}{l}1 \\
4\end{array}$ & Semberong & DS & 130 & 789 & 378 & 1.2 & 23.5 & 84 \\
\hline $\begin{array}{l}1 \\
5\end{array}$ & $\begin{array}{l}\text { Gunung } \\
\text { Ledang }\end{array}$ & DS & 2 & 450 & 150 & 0.0 & 0.3 & 1 \\
\hline $\begin{array}{l}1 \\
6 \\
\end{array}$ & Lingiu & RR & 1561 & $\begin{array}{r}100 \\
6 \\
\end{array}$ & 306 & 0.7 & 370.0 & 1902 \\
\hline $\begin{array}{l}1 \\
7\end{array}$ & Lebam & DS & 20 & $\begin{array}{r}100 \\
6 \\
\end{array}$ & 306 & 0.7 & 3.3 & 44 \\
\hline $\begin{array}{l}1 \\
8\end{array}$ & Congok & DS & 16 & $\begin{array}{r}132 \\
3 \\
\end{array}$ & 424 & 0.8 & 1.0 & 25 \\
\hline $\begin{array}{l}1 \\
9 \\
\end{array}$ & Labong & DS & 16 & $\begin{array}{r}132 \\
3 \\
\end{array}$ & 424 & 0.8 & 13.0 & 45 \\
\hline & PAHANG & & & & & & & \\
\hline $\begin{array}{l}2 \\
0\end{array}$ & Chereh & RR & 1240 & $\begin{array}{r}113 \\
9\end{array}$ & 310 & 0.9 & 250 & 1934 \\
\hline $\begin{array}{l}2 \\
1\end{array}$ & $\begin{array}{l}\text { Kelau/ } \\
\text { Langat }\end{array}$ & RR & 1950 & 997 & 200 & 0.0 & 137.0 & 2420 \\
\hline & $\begin{array}{l}\text { SARAWA } \\
\mathrm{K}\end{array}$ & & & & & & & \\
\hline $\begin{array}{l}2 \\
2\end{array}$ & Sika & DS & 30 & $\begin{array}{r}238 \\
4\end{array}$ & $\begin{array}{r}44 \\
2\end{array}$ & 0.3 & 3.2 & na \\
\hline $\begin{array}{l}2 \\
3 \\
\end{array}$ & $\begin{array}{l}\text { Assyakirin } \\
\text { (Kelalong) }\end{array}$ & DS & 28 & $\begin{array}{r}238 \\
4 \\
\end{array}$ & 442 & 0.3 & 33.7 & na \\
\hline $\begin{array}{l}2 \\
4\end{array}$ & Gerugu & RR & 77 & $\begin{array}{r}178 \\
5\end{array}$ & 299 & 0.4 & 7.8 & 140 \\
\hline $\begin{array}{l}2 \\
5\end{array}$ & Bengoh & RR & 633 & $\begin{array}{r}239 \\
5\end{array}$ & 403 & 0.5 & 137.0 & 2094 \\
\hline & LABUAN & & & & & & & \\
\hline $\begin{array}{l}2 \\
6 \\
\end{array}$ & Bukit Kuda & DS & 2 & $\begin{array}{r}175 \\
9 \\
\end{array}$ & 553 & 0.2 & 4.7 & 8.5 \\
\hline $\begin{array}{l}2 \\
7\end{array}$ & Kerupang & DS & 0.5 & $\begin{array}{r}175 \\
9 \\
\end{array}$ & 553 & 0.2 & 0.2 & 1.0 \\
\hline $\begin{array}{l}2 \\
8\end{array}$ & Sg Pagar & DS & 0.75 & $\begin{array}{r}175 \\
9 \\
\end{array}$ & 553 & 0.2 & 0.4 & 1.5 \\
\hline
\end{tabular}

\subsection{Selection of Dam/Reservoir and Assumptions}

Selection of existing reservoir schemes for evaluation in this Study is based on the following conditions: (1) Operation mode of DS and/or RR reservoir. It appears that PS scheme is not compatible with the modus operandi of SYR model due to the underlying assumptions made during the derivation of SYR (Kuria and Vogel, 2014) model. Therefore, existing PS reservoir schemes were excluded from this exercise. (2) Reservoir scheme for water supply, with exception of a dual function for flood mitigation, where the 
nominal water level is adopted for estimating the corresponding storage volume, (3) Compensation flow at the dam site is not considered in the yield calculation. (4) Assuming the estimated yield by Kuria and Vogel (2014) is deemed as a gross yield, (5) Assumed that the SYR model does not implicitly take into consideration of evaporation losses from the surface of the reservoir. (6) SYR model does not take into consideration of the unique limitation of carryover period as commonly practiced in Malaysia, where the reservoir design criteria and standard is mostly confined to less than 36 months. In theory, the estimated yield by SYR model is limitless with respect to the input variables, such as reservoir storage capacities and inflows. (7) The WTP capacity adopted for comparison is assumed to be the WTP capacity and with due diligence by adding the compensation flow that might have known a priori. In this regard, it is assumed that the sizing of the WTP capacity and dimension is based on the reservoir yield unless expressed otherwise. Therefore, cautions should be exercised while interpreting the results of SYR model vis-à-vis established and prevailing design criteria of Malaysia.

With due consideration of the criteria for the data availability and suitability of the SYR model, 28 dams are selected in this Study. Table 1 shows the input variables and WTP capacity of the selected 28 dams (also see Figure 1).

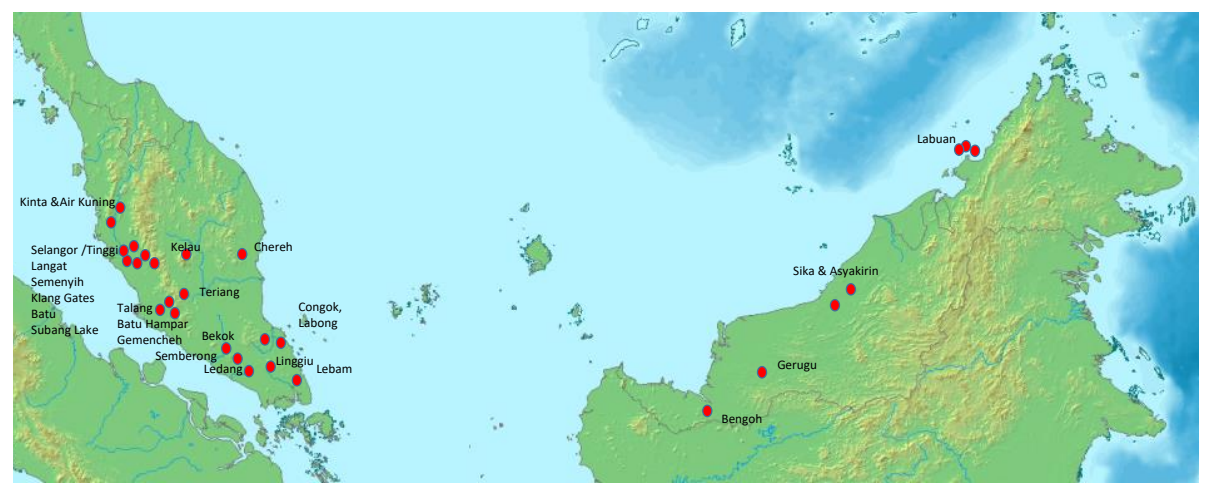

Figure 1. Location Map of 28 Dams in Malaysia 


\subsection{Reservoir Schemes}

There are more than 70 reservoirs/dams spread across various draining catchment areas, and of different sizes in terms of storage capacities and physical sizes. The dams serve multifaceted functions such as providing raw water augmentation to WTPs, generating hydropower, mitigating flood (by holding the torrential flows in the reservoir water body), proving raw waters through various drainage network mainly for paddy irrigation, and others (Shahabudin, 2015).

For convenience of discussion, the reservoir schemes are classified into geographic regions: Northern Peninsular, Central Peninsular, Southern Peninsular, Eastern Peninsular regions, and Sarawak regions. This delineation is also more or less consistent vis-à-vis the climatic as well as hydrological region of Malaysia.

\section{Northern Peninsular Region}

Timah Tasoh $\left(191 \mathrm{~km}^{2}\right)$ is the only dam for dual irrigation and domestic water supply for the northeastern and central region of Perlis. Therefore, it is not considered in this Study.

In Kedah, Ahning dam $\left(122 \mathrm{~km}^{2}\right)$ was originally built with the objective of domestic water supply to both Kedah and northern Perlis. However due to the presence of two additional irrigation dams in the river basin, the day-today operation was managed by the regional irrigation authority, Muda Agricultural Development Authority (MADA), in conjunction with other reservoirs and infrastructure under its mandate mainly for irrigation water supply to downstream irrigation zone. The two irrigation dams are Pedu (171 $\left.\mathrm{km}^{2}\right)$ and Muda dams $\left(984 \mathrm{~km}^{2}\right)$. Major water supply intakes are located at the lower river catchment at Pelubang intake $\left(1076 \mathrm{~km}^{2}\right)$. Essentially raw water sources for domestic water supply is significant considering plentiful of natural residual catchment flows during both average flow regime and regulating releases by both Pedu and Ahning dams to satisfy the seasonal irrigation demand in MADA, which is the largest major granary irrigation region in Malaysia. In 2012, both Pedu and Ahning dams released a total 774 
MCM/year (2121 Mld) for both irrigation and domestic water demand (Baharudin and Arshad, 2015). Only small percentages of these releases of about 200 to 300 Mld were allocated for domestic water supply.

The only water supply dam in Kedah is in the island of Langkawi, where bulks of domestic water supply is mainly supplied by Malut dam $\left(3.5 \mathrm{~km}^{2}\right)$ and two smaller ORS bunded storage located off the bank of Melaka river at Padang Matsirat and Padang Gaong respectively. With its relatively bigger ratio of storage capacity of about 6.9 MCM over the annual inflow, the dam is currently operated under a PS scheme by diverting excess flows during monsoon months at a pumping station downstream of Melaka river basin.

The main raw water sources for both Penang Island and Mainland are currently lagging behind the increasing demand due to industrial and housing development. On the mainland, raw waters are primarily drawn from PS Mengkuang dam scheme, where the augmentation to the dam by a larger inflow of Muda river of more than $4000 \mathrm{~km}^{2}$ at the existing Muda barrage. Mengkuang dam $\left(4 \mathrm{~km}^{2}\right)$ was operated under a PS mode from its inception due to obvious reason of its smaller dam catchment area and availability of relatively voluminous raw waters that can be conveniently transferred via pipeline from Muda river basin. The reservoir capacity was therefore oversized up to $23 \mathrm{MCM}$. Expansion of this PS scheme is currently underway to raise the storage capacity to about $74 \mathrm{MCM}$ and thus the reliable yield of the entire source work system.

On the Pinang Island, both Air Itam $\left(6 \mathrm{~km}^{2}\right)$ and Telok Bahang $\left(10 \mathrm{~km}^{2}\right)$ dams are fed by small rivers. With their relatively smaller scale operation in terms of both catchment area and storage, they only manage to harness relatively smaller yields mainly for domestic water supply within the island. Telok Bahang dam was however, originally designed as a PS scheme but for some unforeseeable reason, it is currently being operated under a DS mode.

There are also 3 smaller size dams in Pulau Pinang, i.e. Cherok Tokun, Berapit, and Bukit Panchor. All of them are located on the mainland. Their sizes in terms of both catchment area and storage volume are smaller, the 
catchment areas are $2 \mathrm{~km} 2,1 \mathrm{~km} 2$, and $66 \mathrm{~km} 2$, for Cherok Tokun, Berapit, and Bukit Panchor dams respectively. The storage volumes are equally smaller of less than 0.3 MCM. They appear to be operated under DS mode and only serve the local smaller capacity demand zone in the vicinity.

\section{Upper Central Peninsular Region}

Two reservoir systems are dedicated for water supply purpose in the upper central peninsular region, namely Kinta $\left(148 \mathrm{~km}^{2}\right)$ and Air Kuning (14 $\mathrm{km}^{2}$ ) dams. Both are operated based on DS mode. Other dam schemes in Perak are Jor (275 km²), Mahang (359 km²), Sultan Abu Bakar (159 km²), are mainly used for hydropower generation in Cameron Highlands. Other large-scale hydropower development is a cascading four reservoirs in series along Perak river, i.e. Temenggor $\left(3506 \mathrm{~km}^{2}\right)$, Bersia $\left(3560 \mathrm{~km}^{2}\right)$, Kenering $\left(5713 \mathrm{~km}^{2}\right)$, and Chederiang $\left(6688 \mathrm{~km}^{2}\right)$. In addition, Bukit Merah dam $\left(480 \mathrm{~km}^{2}\right)$ is a dual function for both irrigation and water supply dam that was built in the earlier 1900 's. It is one of the few older dams built during the colonial era.

Kinta dam (renamed as Sultan Azlan Shah Dam; $148 \mathrm{~km}^{2}$ ) was commissioned in 2006 to provide raw augmentation of water deficit during dry seasons to both Ulu Kinta (136 Mld capacity) and newly constructed Sungai Kinta (227 Mld capacity) WTPs. This is the largest water supply dam scheme in Perak, other than four major cascade hydropower dams in Perak river basin. The total nominal design capacity of the WTPs was designated as 363 Mld which was higher than the estimated yield. By doing so, the reliability criteria reduced from normal $98 \%$ to about $92.5 \%$. Kinta dam was also the first Rolled Compacted Concrete (RCC) dam in Malaysia. The dam was $90 \mathrm{~m}$ high measured from the river bed elevation and with a $670 \mathrm{~m}$ long dam crest. The reservoir that impounds some $40 \mathrm{MCM}$ of river flow was not far from the town of Tanjung Rambutan in the northern region of Perak. Out of this, 10 MCM was designated as dead storage where the invert level of the outlet structure was set. The full supply level (FSL) and embankment crest level (ECL) of Kinta dam are $245 \mathrm{~m}$ and $250 \mathrm{~m}$ LSD respectively. The lake area at FSL is about $1.4 \mathrm{~km} 2$, considering a narrowing gorge topography at the dam 
site as it accounted for only a small fraction of the dam catchment area. As a standard practice for RCC dam, the Ogee type stepped spillway was readily incorporated in the main dam structure as part of the cost saving and efficient design and optimization. The spillway length is $100 \mathrm{~m}$ wide for obvious cost minimization reason.

Air Kuning dam was built in the late 1990's for domestic water supply purpose. It is a small earth fill zoning dam built across river. The catchment area draining at the dam site is about $14 \mathrm{~km}^{2}$. The active storage is relatively small, of about 1.1 MCM which could harness about a gross yield of 24 Mld in direct supply reservoir mode.

\section{Middle Central Peninsular Region}

This region encompasses the entire administrative boundary of Selangor and Kuala Lumpur. In addition, the region is also known as high demand zone with a population of about 6 million and higher demand is forecasted in both long and medium terms. There are six (6) major reservoir systems, an interstate water transfer system from neighbouring state of Pahang, and a pump storage scheme in the southern boundary serving as raw water sources to respectively 29 WTPs. The total output of the reservoir system is about 4500 Mld.

The Selangor river basin is the largest river basin in the state Selangor and drains some $1800 \mathrm{~km}^{2}$ at the estuary. The river basin is undulating landform with mix land use practices, mainly forested and minor agricultural plantations. It remains primarily rural with only sporadic townships scattering along the main stem of the river.

Two dams in parallel operating mode, Tinggi and Selangor dams $\left(40 \mathrm{~km}^{2}\right.$ and $197 \mathrm{~km}^{2}$ ) are located at the upper headwater basin to provide augmentation of flows to a downstream intake near the estuary. These two dams form major water supply scheme to Selangor and Kuala Lumpur as they are accounted for some $60 \%$ of the total domestic water demand in Selangor and Kuala Lumpur. In addition, a 150 Mld capacity pump refilling scheme was also implemented 
in tandem to speed up refilling of Tinggi reservoir during higher flow regime in Selangor river to within a reasonable time frame of 24 to 36 months.

The Langat river basin forms the southern boundary of Selangor and a small portion of the drainage area partially encroaches into the neighbouring Negri Sembilan administrative boundary. The upper catchment near the dam site comprises generally rugged and undulating mountain terrain with multiple rural land use classification. However, the vast majority of land use remains undisturbed primary forest especially in non-accessible and remote regions of the upper river basin.

Two major existing dams, Langat and Semenyih dams $\left(41 \mathrm{~km}^{2}\right.$ and 57 $\mathrm{km}^{2}$ ) are located at the headwater tributaries of Langat river basin. This combined output of about 1000 Mld was the largest in the Langat river basin until it was overtaken by the joint Selangor dam and Tinggi dam on Selangor river scheme of ultimate 3000 Mld in the late 1990's.

In the central region, two dams, Klang Gates and Batu are both located in the upper headwater catchment of Klang river basin; drain some 77 and 50 $\mathrm{km}^{2}$ of the catchment areas respectively. The reservoir storage capacities (combined live storage of about $47 \mathrm{MCM}$ ) and reliable yields are only a small fraction of Selangor, Langat, and Semenyih dams. Total combined plant capacity of these two dam schemes is about $250 \mathrm{Mld}$. Both dams are also being operated as flood control reservoir where substantial reservoir capacities above the full supply level are reserved for flood waters in time of monsoonal season. Therefore, their potentials for future upgrading and retrofitting are basically limited unless forgoing the flood mitigation function of the reservoir by raising the nominal reservoir level. The schemes are also being over their useful capacity. A 45-Mld capacity Wangsa Maju WTP also taps raw water sources directly from Klang Gates reservoir during normal flow regime. When the reservoir water level reaches a pre-designated low level, the diversion would therefore stop, and the remaining raw water is augmented by a defunct pumping scheme from neighbouring Gombak river basin. At present clean water distribution operation, the deficit in potable water supply is 
essentially augmented by treated water transfer from northern Selangor water supply scheme.

Compared to other reservoir schemes in Selangor, Subang lake reservoir/dam is a much smaller water supply scheme commissioned in the earlier 1950's. It drains a smaller tributary of Buloh River, to the northwestern corner of Klang river basin. It is located $30 \mathrm{~km}$ west of Kuala Lumpur to supply mostly the western coastal region of Selangor. The dam that drains about $10.3 \mathrm{~km} 2$ of the pristine forest covered Buloh river catchment area provides a steady raw water source to North Hummock WTP of about 23 Mld in capacity. The yield under DS was known to be slightly lower and thus the WTP is almost operated under overloading albeit manageable condition. The reservoir scheme serves its intended purpose well but due to urbanization in the surroundings that demand higher potable water supply, the scheme is currently undergoing a rigorous appraisal to increase its output by switching into PS mode of operation. This is accomplished by capturing excess runoff during storm events to refill its future bigger storage capacity by dam raising proposal.

This PS scheme in Labu river was initiated as dedicated raw water sources for expanded KLIA water supply scheme and townships in its immediate vicinity. A low bunded storage of about $4 \mathrm{MCM}$ was built by the right bank of Labu river. During higher flow regime of monsoon months, excess runoff is pumped into the bunded storage for latter utilization. At the meantime, due to its relatively longer hydraulic detention time, it can also provide some water quality polishing capacity by converting (via oxidation) dissolved ammonia $\left(\mathrm{NH}_{3}\right)$ to nitrate $\left(\mathrm{NO}_{3}\right)$ by natural aeration process within the bunded storage water body.

\section{Lower Central Peninsular Region}

There are seven water supply reservoir schemes in Negeri Sembilan. Out of these, Terip $\left(26 \mathrm{~km}^{2}\right)$, Kelinchi $\left(37 \mathrm{~km}^{2}\right)$, and Talang $\left(148 \mathrm{~km}^{2}\right)$ are configured as a PS mode of raw water interbasin transfer ultimately transferring to Terip dam via Kelinchi dam from Talang dam. Both recent 
Teriang $\left(60 \mathrm{~km}^{2}\right)$ and Batu Hampar $\left(15 \mathrm{~km}^{2}\right)$ dams are operated under RR mode, whereas both Gemencheh $\left(35 \mathrm{~km}^{2}\right)$ and Beringin/Pedas $\left(5.5 \mathrm{~km}^{2}\right)$ are operated based on DS mode.

Due to recent commission of Teriang reservoir scheme, a slight change of operation in Talang-Kelinchi-Terip system by relieving Talang dam from transferring bulk of reservoir storage to Terip dam. With this in mind, Talang dam can now switch its operational mode from PS to RR at Kuala Jelai intake $\left(1151 \mathrm{~km}^{2}\right)$ in Muar river basin. The reservoir operates on a RR mode in such a way by timely releases to augment low flows, in other words, by releasing waters from the reservoir at the existing water supply intakes at downstream Kuala Jelai WTP.

Teriang river originates from the hilly area of the main range in Jelebu district and flows northeast direction to join greater Pahang river. The catchment area of Teriang river basin within administrative boundary of Negeri Sembilan is about $1200 \mathrm{~km}^{2}$. The headwater region is in the hilly terrain, which forms part of the Titiwangsa mountain range that runs along the middle of the Peninsular Malaysia. The basin is bounded in the west by Sg. Semenyih (part of Sg. Langat basin), in the north and east by Pertang river and upper Sg. Muar basins and in the south by Linggi river basin respectively. The catchment is located at one of the driest regions in Malaysia.

Teriang scheme is a RR mode of operation with an intake located at the downstream of Teriang river before joining the Pahang river. The intake catchment at Petasih drains some $796 \mathrm{~km}^{2}$ with Teriang dam $\left(60 \mathrm{~km}^{2}\right)$ located in the headwater region of Teriang river. The scheme could supply up to 500 Mld of reliable yield in additional of about 100 Mld compensation past the Petasih intake. This adds to 600 Mld of gross yield harnessed for the ultimate phase of RR mode of reservoir operation.

Gememcheh dam $\left(35 \mathrm{~km}^{2}\right)$ is located at the upper $\mathrm{Sg}$. Gemencheh catchment, one of the major tributaries of Sg. Muar in Negeri Sembilan. The reservoir was commissioned in 1999 to regulate flows at the downstream Gemencheh WTP intake $\left(60 \mathrm{~km}^{2}\right)$ near the town of Gemencheh. The reservoir 
was originally designed as a RR mode to release waters during prevailing low flow downstream at the Gemencheh WTP intake. Due to persistently low rainfall in the river basin, the operation was inadvertently switched to DS mode. As a result, the reservoir was considered overcapacity. A recent PS scheme of 50 Mld capacity interbasin transfer from Jelai river, another tributary of Muar river was commissioned. The 45-Mld design capacity WTP supplies treated waters to both districts of Rembau before en route to Tampin. It appears that that the reservoir scheme was oversized with unexpected shortfall in the natural dam inflows. In addition, the reservoir is located at the lowest rainfall region of Peninsular Malaysia.

Batu Hampar dam (renamed as Ulu Sepri, $15 \mathrm{~km}^{2}$ ) is located at the headwater region of Batu Hampar river, one of the tributaries of Rembau river. An intake is located at further downstream of Rembau river $\left(222 \mathrm{~km}^{2}\right)$ for diverting high flow to the 100 Mld capacity WTP nearby. The purpose of the intake with its gated barrier is to divert waters by raising its hydraulic head for gravity flow. In case of shortage of unregulated streamflow at the intake, releases from the dam is only required at a head of time based on the streamflow forecast.

Beringin dam $\left(5.5 \mathrm{~km}^{2}\right)$ is a small and low 14-m high concrete dam across Pedas river in the central region of Negeri Sembilan. The storage capacity of the reservoir is only $0.525 \mathrm{MCM}$. It serves to supply raw water directly to Pedas WTP of 13.5 Mld design capacity. Considering the catchment area and its location in the driest part of Peninsular Malaysia, it appears that the WTP capacity is not designed based on the results of the DS reservoir yield exercise.

\section{Southern Peninsular Region}

Melaka is a "rain shadow" and water deficit state with only two major dams to serve its entire population in one of the driest regions of Peninsular Malaysia. Existing Durian Tunggal dam $\left(43 \mathrm{~km}^{2}\right)$ and Bund Storage (approximately 1 MCM capacity near PAM intake) regulates the PAM intake $\left(504 \mathrm{~km}^{2}\right)$ by securing raw waters to WTPs in the vicinity. In addition, there is also an existing inter basin river transfer scheme form $\mathrm{Sg}$. Muar of about 
220 Mld to Bertam and Sebukor WTPs in Melaka river basin. In this way, the Bertam (both Lama and DAF) and Sebukor WTPs of total 372 Mld (JPS, NWRS Review, 2011) at PAM intake tap their raw water resource by reservoir regulation from Durian Tunggal dam and interstate river basin transfer. Some of the excess in Durian Tunggal dam can be transferred Jus dam $\left(22 \mathrm{~km}^{2}\right)$ by pumping facility, i.e. about $35 \mathrm{Mld}$ (slightly more than $1 \mathrm{MCM} / \mathrm{month}$ ). Other than this connection to Jus dam, this system is however considered as an entirely separate and independent water supply scheme in Sg. Melaka basin.

The inception of Jus dam $\left(22 \mathrm{~km}^{2}\right)$ was the solution to the increasing demand in Melaka and the aftermath of Durian Tunggal dam's nearly dry up episode during the middle of 1990's. The mismanagement and slag in operation and maintenance of the dam structure led to almost complete drying up of its entire storage capacity. As a result, water rationing lasting for several months was imposed for the first time in the history of water supply sector in Melaka. The intent of the existing Jus dam was to regulate both Batang Melaka at Gadek intake (230 $\mathrm{km}^{2}$; WTP capacity is $\left.55 \mathrm{Mld}\right)$ and Chin Chin (394 km2; 20 Mld), Merimau (formerly known as Lanchang) intake (550 km²; $110 \mathrm{Mld})$ in neighboring Kesang river basin. On both Melaka river and its tributary, Batang Melaka river basins, a small run-of-river scheme (4.5 Mld) near Jus dam/reservoir. This is considerably smaller scheme and it is not considered in the subsequent yield estimation exercise. On the other hand, another small-scale reservoir scheme, Asahan dam $\left(2 \mathrm{~km}^{2}, 0.3 \mathrm{MCM}\right)$ is located at the upper Chohong river basin near the border of Melaka and Johor. This is a small localized direct supply scheme and would not be taken into consideration in the yield calculation and comparison in this Study.

The existing dual purpose Bekok dam $\left(350 \mathrm{~km}^{2}\right)$ for flood control and domestic water supply was constructed in the earlier 1990's. The nominal pool level (NPL) is set at $13.3 \mathrm{~m}$. The corresponding gross storage is $32 \mathrm{MCM}$ out of which, $8 \mathrm{MCM}$ is dedicated for dead storage mainly for 100-year sediment storage. The embankment level of the dam is $23.0 \mathrm{~m}$. The most recent review recommended raising the dam height to $16.0 \mathrm{~m}$ so that the 
conservative storage can be increased. The reliable yield of 1:50 year return period of the original design was reconfirmed at $170 \mathrm{Mld}$ with a $40 \mathrm{Mld}$ as compensation flow. A raw water intake at the dam site or draw-off tower was constructed in 2009 to facilitate gravity transfer to Sri Gading and Yong Peng WTPs, of a total capacity of about 157 Mld. Raising of dam height was also currently been considered in a new investigation. By raising the conservative storage to about $78 \mathrm{MCM}$, an incremental yield of about 70 Mld can be harnessed by this dam raising exercise. The compensation flow was remained at 40 Mld. This would provide a gross yield of 280 Mld post retrofitting exercise. This would need to raise the dam embankment by $1.0 \mathrm{~m}$ in the form of parapet wall along the $700 \mathrm{~m}$ long dam crest. This is essential for safe passage of floods of PMP/PMF magnitude by not overtopping the dam crest.

Semberong dam $\left(130 \mathrm{~km}^{2}\right)$ is another existing irrigation dam scheme constructed in tandem in Batu Pahat river basin. The dam was originally designed for irrigation water supply for southwest Johor regional irrigation scheme, but it is currently being opted to provide a DS mode of raw water supply to a 76 Mld capacity Parit Raja WTPs. The gross storage capacity of the reservoir is $26.5 \mathrm{MCM}$, out of this, 3.0 MCM is considered as dead storage slightly above the MOL level.

Gunung ledang $\left(2 \mathrm{~km}^{2}\right)$ is a smaller dam on Tengkak river with a 0.3 MCM storage capacity. The DS scheme supplies raw water to Tangkat WTP. The reliable yield is small, i.e. less than 1.0 Mld could be harnessed due to both smaller catchment area and storage capacity.

The existing Linggiu dam (208 $\mathrm{km}^{2}$ ) was built in the middle of 1990's to augment raw water deficit during low flow river regimes at the downstream Johor River Water Works (JRWW: 1137 Mld capacity) by a joint Public Utility Board (PUB) Singapore and Malaysia Water Department in an international water transfer compact (Ewing and Domondon, 2016). The upstream of the reservoir catchment has a rugged terrain and topography with sharp crest and steeper slopes. The area is above $100 \mathrm{~m}$ LSD with the higher mountain ranges reach about $440 \mathrm{~m}$ LSD next to bigger Endau river basin in 
the north. The low main dam with an FSL of $51 \mathrm{~m} \mathrm{LSD}$ was constructed across a wider river valley on the main stem of Linggiu river. Four saddle dams were also constructed concurrently on the left abutments of the main dam. Johor river basin is currently the one of the largest southern region raw water sources to various demand zones in highly urbanized Johor Bahru and its vicinity other than transfer via pipeline to Singapore. It also contributes to some $40 \%$ of Singapore water supply until 2061 (1157 Mld or 250 MGD is delivered via pipeline across the Malaysia-Singapore causeway). In the upper remote Johor river headwater region, Linggiu dam is currently in operation to regulate low flow regime at the downstream Johor River Water Works (JRWW, nominal capacity of $1157 \mathrm{Mld}$ ) intake and various WTP schemes at the upper reach, such as Semangar $1 \& 2$, Sungai Johor phase $1,2, \& 3$, and other minor run-of-river (ROR) abstraction along the upstream tributaries of Johor river, such as Sayong, Bandar Tenggara, and FELDA schemes.

The construction of JRWW barrage was recently completed. The primary purpose of the barrage is to prevent saline intrusion during diurnal high tides and low flow regime. This however brought a positive consequence to the existing water supply scheme as the compensation flow of about 500 Mld could be reduced drastically to about 100 Mld with the barrage operation. Thus, this resulted in an additional 400 Mld of reliable yield could be readily harnessed. The existing yield available under present hydrological regime with barrage configuration was currently assessed at about 1902 Mld (Heng et al. 2017). However, the existing capacity with the construction of a barrage/barrier and abstraction is about $2028 \mathrm{Mld}$. Thus, a deficit of $126 \mathrm{Mld}$ must be augmented by exploring new sources. The Linggiu RR water supply would be eventually phased out and switched to a PS mode by refilling the reservoir storage with transfer of raw waters from neighbouring Johor catchment or raw water transfer from the much bigger northern river basins such as Endau river by taking into advantage of higher flow generated during monsoon season. 
Labong dam $\left(16 \mathrm{~km}^{2}\right)$ was originally built for irrigation water supply scheme in the northeastern corner of the state of Johor in the late 1940's. However, in the latter years it also provides raw water sources for water treatment plants in the vicinity. Labong dam is a small earthfill embankment located at the north-eastern corner of Johore. It is located across the narrow river valley, about $5.5 \mathrm{~km}$ upstream of the confluence of Labong and Endau Rivers. The dam was constructed in 1949 to supply water to for the Endau Plain Irrigation Scheme, Stage 1. This scheme covers an area of about 1184 Ha. Presently, due to reduction in irrigation activity in the valley (only about $754 \mathrm{Ha}$ is cultivated) the impounded water is also utilized by Syarikat Air Johor (SAJ) for domestic water supply to localized Endau town and vicinity. The present water supply capacity is about 2.2 Mld and can be increased for future demand with retrofitting to pump storage scheme.

Lebam $\left(20 \mathrm{~km}^{2}\right)$ is a DS type of water supply dam that drains some 20 $\mathrm{km}^{2}$ of upper Lebam river, a southern most tributary of greater Johor river basin. The storage is relatively smaller, i.e. 3.0 MCM if compared to the annual inflows that could reach $20 \mathrm{MCM} /$ year if assuming a conservative annual average flow (AAF) of $1000 \mathrm{~mm} / \mathrm{year}$. There is planned to upgrade the reservoir scheme to PS mode by increase the capacity and dam height and with supplement inter basin transfer from neighbouring Chemanger river catchment. The WTP capacity is 44 Mld.

Congok dam $\left(15 \mathrm{~km}^{2}\right)$ supplies raw water to 14 Mld capacity Tenglu WTP downstream via penstock. The storage is about 1.0 MCM and there is potential for PS scheme retrofitting exercise by dam raising due to its higher annual runoff in the eastern coastal region of Peninsular Malaysia.

Other reservoir schemes, Seluyut dam-Sedili river, series reservoir of Upper and Lower Layang dam, and Pulai dam system (inter basin transfer and connection amongst 4 dams, Pulai 1, 2, and 3, and Pontian Kecil) are essentially PS scheme. Therefore, they are not considered in the yield comparison exercise in this Study. Kenyir dam $\left(2600 \mathrm{~km}^{2}\right)$ is one of the largest hydropower dams in Peninsular Malaysia. With its sizable storage of 13600 
MCM, it can provide constant firm power to grid network for the entire Peninsular. On the other hand, Pergau dam $\left(164 \mathrm{~km}^{2}\right)$ and relatively smaller impoundment of about $62.5 \mathrm{MCM}$, is operated as a peaking power plant by generating power during peak hour demand.

\section{East Coast Region}

With relatively sparse population and low and passive in demand of both industrial and domestic sector, this region does not require a storage provision in order to secure reliable raw water yield to the respective WTPs. Only exceptions are two significant reservoir schemes in Pahang, i.e. Kuantan river of Kuantan river basin and Semantan-Kelau river of Pahang river basin. The latter scheme is nevertheless for westward interbasin transfer to high demand area in neighboring Selangor and Kuala Lumpur. Keryih

Chereh RR system is located on Chereh river, one of the major tributaries of Kuantan river. This RR operating system could harness about 1934 Mld. The catchment areas for Chereh reservoir and Kobat intake 152 and $1240 \mathrm{~km}^{2}$ respectively. Kuantan Barrage was constructed in 1985 for primary purpose to exclude saline intrusion during periods of low flow and high tide, such that extraction of raw water at the existing intake at Kobat to be made possible. The physical dimension of the barrage structure is about $300 \mathrm{~m}$ in width with 7 vertical lift gates. The barrage site is located a short distance downstream of the Kobat intake at the outer bank of the river bend to facilitate ease of water diversion. The diverted is piped to the Kobat intake to replace the previous direct run-of-river intake configuration.

Chereh dam is located about $44 \mathrm{~km}$ northwest of Kuantan and some 11 $\mathrm{km}$ northward of a major township, Lembing river at the upper Kuantan river catchment. The catchment is a fan-shaped type basin and consists mainly of hilly and steep slope in the upper reaches with mountain peak up to $625 \mathrm{~m}$. The land use is predominantly virgin and logged-over secondary forest. Currently the catchment areas, at the future lake water body are undergoing logging activities in anticipation of the current dam construction in progress. 
Kelau dam $\left(331 \mathrm{~km}^{2}\right)$ RR scheme is a newly commissioned large-scale inter-river basin raw water transfer from a water rich basin in Pahang to water deficit Selangor and Kuala Lumpur. The complete scheme delivers raw waters from an intake downstream of Kelau/Semantan river by pipeline to neighbouring Langat river basin in Selangor via a 45-km long tunnel bored through the central range of Titiwangsa mountain. The ultimate scheme can sustain a 1:50-year net yield of about 1890 Mld at the most downstream Semantan intake $\left(1950 \mathrm{~km}^{2}\right)$. Due to its larger draining catchment at the intake, the RR scheme can comfortably deliver the design yield for raw water supply while at the mean times, maintaining a healthy compensation flow past the intake to satisfy the various lower Semantan intakes and/or stack holders before joining the main stem of Pahang river near Temerloh. The environmental release is about $10 \%$ of AAF (530 Mld) based on $991 \mathrm{~mm} /$ year runoff depth and catchment area at intake $\left(1950 \mathrm{~km}^{2}\right)$.

\section{Sarawak Region}

The existing Bengoh dam commands a catchment of $127 \mathrm{~km}^{2}$ in the headwater region of Sarawak river basin. The dam was constructed in the late 2000 's with the primary purpose of securing raw water sources for Batu Kitang intake WTPs at downstream. The storage volume of Bengoh dam is 144 MCM. With its sizable storage and abundance inflows in the upper Sg Sarawak Kiri basin, the reliable yield could be substantial about 1960 Mld to fulfil both the current and future water demand at least up to 2050 and beyond for Kuching and its vicinities. Within the river basin, two existing Matang and Sebutan dam, are of smaller storage capacity, i.e. 0.5 and 0.1 MCM on Matang river and China River respectively, both are minor tributaries of Sarawak river. With the commission of Bengoh dam, their roles to provide secure water yield seem limited to satisfy small scale local demand in the northern region of Sarawak river basin.

Gerugu dam $\left(14 \mathrm{~km}^{2}\right)$ is a zoned earthfill dam located in the headwater region of Sarikei river. The scheme is operated in a RR mode. The existing Bayong intake encompassing a catchment area of about $91 \mathrm{~km} 2$ diverts river 
flow into the Sarikei WTP during normal or average flow regime. In anticipation of water deficit during prevailing drought season from May to August, reservoir releases are then made from the dam to compensate the difference in raw water quantity.

Assyakirin dam $\left(28 \mathrm{~km}^{2}\right)$ is located about $20 \mathrm{~km}$ northeast of Bintulu on one of the major tributaries of Sibiu river. The dam operates on DS mode and was commissioned for Bintulu water supply stage 3 project. The $30-\mathrm{m}$ high zoned earthfill dam is located across the narrow Kelalong river valley. The dam crest is about $460 \mathrm{~m}$ long. The gross reservoir storage is $33.7 \mathrm{MCM}$, out of this, about 1.0 MCM is dedicated to dead storage for 100 -year sediment accumulation.

\section{Labuan Island Region}

There are three existing dams/reservoirs in Labuan Island. These are smaller dams in terms of their sizes and storage capacities. The catchment areas and storage capacities at Bukit Kuda, Kerupang, and Sg. Pagar dams are 2, 0.5, and 0.75 km2 and 4.7, 0.2 and 0.4 MCM respectively. Both Bukit Kuda and Kerupang dams are serving the Jalan Kolam WTP (14 Mld in capacity). On the side of the Island, the Sg. Pagar dam supplies a small WTP of the same name on the eastern region of the island. Bukit Kuda dam is the largest dam in terms of both catchment area of $2.0 \mathrm{~km}^{2}$ and storage capacity of about 4.74 MCM was originally designed as a PS scheme with over size capacity since its own natural catchment runoff could not refill timely. An augmentation pump refill scheme from a bigger catchment downstream was added to the scheme by conveyance via pipeline to the dam site. However, the pump refilling operation was halted due to a host of technical problems in pump stations and other associated facilities. The water supply for the island is now obtained exclusively from the mainland via submarine pipeline system.

\section{Results and Discussion}

A 1:50-year reservoir yield calculation for 28 systems (17 DS and $11 \mathrm{RR}$ ) was carried out using the SYR model (Kuria and Vogel, 2014). Criteria for evaluation and comparison in tandem was primarily based on goodness of fit 
of respective estimated SYR yield is-à-vis established or known yield (derived from WTP capacity and yield review studies). By compared to the WTP capacity, the difference in general, less than a factor of two, i.e. 50\% lower and $100 \%$ higher margin. A log-log graphical plot of the estimated SYR yields vis-a-vis WTP capacity shows some degrees of agreement that the calculation falls within a band of upper and lower bounds in a logarithmic graphical plot.

The difference in SYR yield (214 Mld) and WTP capacity (363 Mld) for Kinta DS dam scheme was about $41 \%$ however this disparity cannot be compared directly in a conventional way, as the total WTP design capacity in its original intents and inception was not designed based on a 1:50-year return period. Therefore, it should be taking into cognizance that the comparison of such could not be possible under different criteria. On the other hand, NWRS Review (JPS, 2011) reported a gross yield of about 269 Mld for existing Kinta dam DS operation. Nevertheless, this was also higher than the SYR yield but the gap in difference was much narrower vis-à-vis design WTP capacity of 363 Mld.

In the central Peninsular region of Selangor and Kuala Lumpur, the SYR yield results is consistent with the actual WTP capacities for the existing 6 dam DS and RR schemes. The percentages of difference range from $-32 \%$ to $7 \%$, well within the factor of 2 envelope of goodness-of-fit line. The only exception was higher gross yield by SYR model (Kuria and Vogel, 2014) for Semenyih dam scheme where the difference in overestimation by SYR model was more than $32 \%$ than the WTP capacity.

Teriang dam scheme in its ultimate design was a RR scheme. The SYR yield of 697 Mld was comparable to the gross yield of about 600 Mld. Both the SYR yield and WTP capacity of Batu Hampar and Talang RR schemes were comparable within an acceptable limit, i.e. lower than $20 \%$ in differences. On the other hand, Gemencheh dam DS scheme was higher at about $44 \%$ due to the bigger storage facility that was originally intended for a RR operation system. SYR yield is sensitive to the storage capacity input. If 
the storage were to be smaller, then the difference between the SYR yield and WTP capacity would be logically lower to an acceptable margin of error.

Six out of seven southern Peninsular dams assessed in this study are of DS operation mode type. Only Linggiu dam is currently operating under a RR mode with joint dam regulation at JRWW intake, further downstream near the Johor river estuary. Bekok dam is a DS scheme with a relatively larger catchment area compared to its nominal conservative storage. It is a dualpurpose dam for both water supply and flood mitigation purpose upstream of Batu Pahat. At the meantime, water contained in the conservative storage of about 30 MCM can be utilized for domestic water supply to both Parit Raja and Sri Gading WTPs. In contrast, the flood storage is about 170 MCM above the NPL. The SYR yield (304 Mld) was $45 \%$ more than the WTP capacity (210 Mld), which is construed as a gross storage inclusive of compensation release downstream of the dam.

The SYR of Semberong DS system (138 Mld) was overestimated by about $64 \%$ over the WTP capacity of 84 Mld. Considering the former role of this dam mainly for paddy irrigation in its original design which tends to be larger in storage capacity, it was a high possibility of the dam was designed to base on the seasonal irrigation water demand vis-à-vis a constant draft for domestic water supply. Besides the design criteria of the irrigation dam is also based on a lesser stringer return period, i.e. 1:5-year or $80 \%$ reliability, compared to strict 1:50-year return period.

Lebam, Congok, and Labong dams of both smaller catchment areas and storage capacities, are located at the eastern coastal region of Peninsular Malaysia where the prevailing monsoonal storm could refill the reservoir storage to its brim within a shorter period of one to three months. In essence, SYR yields of these dams are generally underestimated and there is opportunity for additional yield by either expanding their storage capacities or switching to a PS mode of reservoir operation. By checking on the ratios of inflow to the storage capacity, they were ranged from as low as 1.63 to as high as 21.2. This was basically indicative of the possibility of expansion where 
the existing storage capacity could be increased to cater for excess inflow which will otherwise be frequently spill over to waste.

Linggiu dam RR scheme with its downstream intake at JRWW was originally designed as a PS scheme with pump refilling from Sayong river subbasin within the Johor river basin. The reservoir capacity of $760 \mathrm{MCM}$ was designed to the hydrological limit by catering for ultimate PS scheme. During the interim period, Linggiu dam and JRWW intake (with the recent construction of the barrage that has essentially provided an additional $400 \mathrm{Mld}$ yield) were operated under RR mode with a gross yield of about 1902 Mld. Heng et al (2017a) indicated that the drawdown of the most critical event was only depleting the reservoir storage up to about $370 \mathrm{MCM}$, essentially with a remaining half of the existing storage capacity of about $390 \mathrm{MCM}$ unutilized. However the maximum carryover period (a full-empty-full cycle) would take about 5 to 6 years. The gross yield of 1902 Mld was assumed to be the WTP capacity for comparison vis-à-vis the SYR yield of about 2415 Mld, about $28 \%$ higher than the former.

The SYR yield of Chereh and Kelau/Langat schemes were comparable to the WTP capacity albeit slightly both were been slightly overestimated, with marginal percentages of difference of about -7 and $-11 \%$. It was opined that the margin of error was reasonably consistent and generally acceptable for the macroscopic undertaking in yield estimation.

Four dam schemes in Sarawak were adopted in this Study. Unfortunately, due to uncertainty in the WTP capacity that obtained their entire raw water sources from Sibiu river basin, comparison vis-à-vis SYR yield, for both Asyyakirin and Sika dam schemes was therefore not made in this Study.

The SYR yield for Gerugu dam and Bayong intake RR scheme was 195 Mld vis-à-vis 140 Mld WTP capacity. If taking into consideration of compensation flow, the difference between SYR yield and WTP capacity would be much narrower. Bengoh dam and Batu Kitang intake RR system could harness a reliable yield of 1984 Mld with a 110 Mld compensation flow at Batu Kitang intake. In theory, the ultimate yield of the various phases of 
treatment plant planning could reach up to this maximum threshold level. However, the present various package of WTP in the Batu Kitang WTP complex only reached up to 500 to 550 Mld. SYR yield was estimated at about 2351 Mld about 12\% more than the WTP capacity of about 2094 Mld.

Three domestic water supply schemes (Bukit Kuda, Kerupang, and Sg. Pagar) on the Labuan Island are relatively small DS schemes compared to other water supply dam schemes in Malaysia. The SYR yields for three schemes were consistent with the WTP capacity, although the percentages of difference ranged from as low as 10 to as high as $-44 \%$. Their physical roles in securing raw water sources within the island of Labuan are fairly limited to emergency and risk management due to the main bulk of treated waters are currently obtained from the mainland via undersea pipeline. However, in case of submarine pipeline failure and/or ancillary work malfunction, although smaller in storage volume, they could at least provide some relieves as alternative raw water sources to the respective WTPs at least for a few days prior to full restoration of across the sea water transfer.

For brevity, comparison of the estimated SYR yields and WTP capacity is plotted on a log-log graph with a goodness-of-fit line and its associated factor of two curves. Majority of the SYR yields and WTP capacity lied within the range of factor of two. The slope of regression and coefficient of determination (R2) were 0.89 and 0.98 respectively, indicative of a reasonable fit of the regression curve between SYR yield and WTP capacity. Another empirical parameter, percentage of regulation (PR) which is defined as the percentage of the reservoir yield that could be harnessed with respect to the average annual dam inflow or AAF. It could be interpreted as the yield efficacy of the reservoir system vis-à-vis the baseline run-of-river (ROR) yield. By provision of a storage facility, the reliable yield can be increased by several folds if compared to the base scenario without storage (as represented by the ROR yield such as 7Q50). The average PR for 28 dams in this Study was reasonable at about $55 \%$ with both minimum and maximum PR of $31 \%$ 
and $80 \%$ respectively. Table 2 and Figure 2 show the results of yield estimation by SYR and WTP capacity as plotted on a log-log plot. 
Table 2. Comparison of Estimated Yield by Kuria and Vogel (2014) and

\section{WTP Yield}

\begin{tabular}{|c|c|c|c|c|c|c|c|c|c|c|c|c|c|c|c|}
\hline & Dam & TYPE & Catchment & AAF & SD & AAF & SD & SKEW & 2 & Storage & Yield & \multirow{2}{*}{$\begin{array}{r}\text { Yield } \\
\text { Mld }\end{array}$} & \multirow{2}{*}{\begin{tabular}{|r|} 
\\
$\%$
\end{tabular}} & \multirow{2}{*}{$\begin{array}{r}\text { WTP } \\
\text { Mld }\end{array}$} & \multirow{2}{*}{\begin{tabular}{|r} 
Difference \\
$\%$
\end{tabular}} \\
\hline & & & \multicolumn{2}{|c|}{\begin{tabular}{|l|l|}
$\mathrm{km} 2 \mathrm{~mm} /$ year \\
\end{tabular}} & $\mathrm{mm} /$ vear & MCM/year $\mathrm{A}$ & MCM/year & nd & nd & \multicolumn{2}{|c|}{ MCM $\mathrm{MCM} /$ year } & & & & \\
\hline & PERAK & & & & & & & & & & & & & & \\
\hline 1 & Kinta & DS & 146 & 836 & 175 & 122.1 & 25.6 & 0.2 & 2.054 & 30.0 & 78.1 & 214 & 64 & 363 & 41 \\
\hline \multirow[t]{2}{*}{2} & Air Kuning & DS & 16 & 1458 & 437 & 23.3 & 7.0 & 0.1 & 2.054 & 1.8 & 10.4 & 28 & 45 & 25 & -14 \\
\hline & SELANGOR & & & & & & & & & & & & & & \\
\hline 3 & Selangor/Tinggi & RR & 1554 & 1294 & 264 & 2010.9 & 410.3 & 0.3 & 2.054 & 230.0 & 1103.6 & 3023 & 55 & 3000 & -1 \\
\hline 4 & Langat & RR & 254 & 1376 & 307 & 349.5 & 78.0 & 0.5 & 2.054 & 34.1 & 183.7 & 503 & 53 & 544 & 7 \\
\hline 5 & Semenyih & RR & 571 & 1253 & 282 & 715.5 & 161.0 & 0.5 & 2.054 & 60.4 & 363.0 & 994 & 51 & 751 & -32 \\
\hline 6 & Klang Gates & DS & 77 & 1084 & 285 & 83.5 & 21.9 & 0.9 & 2.054 & 19.3 & 50.1 & 137 & 60 & 145 & 5 \\
\hline 7 & Batu & DS & 50 & 1230 & 292 & 61.5 & 14.6 & 0.2 & 2.054 & 27.5 & 42.5 & 117 & 69 & 115 & -1 \\
\hline \multirow[t]{2}{*}{8} & Subang Lake Meru & DS & 10.3 & 1233 & 290 & 12.7 & 3.0 & 0.1 & 2.054 & 3.5 & 8.0 & 22 & 63 & 23 & 4 \\
\hline & NEGERI SEMBILAN & & & & & & & & & & & & & & \\
\hline 9 & Teriang & RR & 796 & 650 & 143 & 517.4 & 113.8 & 0.0 & 2.054 & 50.0 & 254.5 & 697 & 49 & 600 & -16 \\
\hline 10 & Batu Hampar & RR & 222 & 979 & 283 & 217.3 & 62.8 & 0.0 & 2.054 & 3.0 & 67.1 & 184 & 31 & 222 & 17 \\
\hline 11 & Talang & RR & 1114 & 576 & 276 & 641.7 & 307.5 & 1.6 & 2.054 & 37.0 & 237.2 & 650 & 37 & 500 & -30 \\
\hline \multirow[t]{2}{*}{12} & Gemencheh & DS & 35 & 388 & 284 & 13.6 & 9.9 & 1.5 & 2.054 & 30.0 & 9.2 & 25 & 68 & 45 & 44 \\
\hline & JOHOR & & & & & & & & & & & & & & \\
\hline 13 & Bekok & DS & 350 & 789 & 378 & 276.2 & 132.3 & 1.2 & 2.054 & 24.0 & 110.8 & 304 & 40 & 210 & -45 \\
\hline 14 & Semberong & DS & 130 & 789 & 378 & 103 & 49.1 & 1.2 & 2.054 & 23.5 & 50.3 & 138 & 49 & 84 & -64 \\
\hline 15 & Gunung Ledang & DS & 2 & 450 & 150 & 0.9 & 0.3 & 0.0 & 2.054 & 0.3 & 0.5 & 1 & 58 & 1 & -42 \\
\hline 16 & Linggiu & RR & 1561 & 1006 & 306 & 1570.4 & 477.7 & 0.7 & 2.054 & 370.0 & 886.4 & 2428 & 56 & 1902 & -28 \\
\hline 17 & Lebam & DS & 20 & 1006 & 306 & 20.1 & 6.1 & 0.7 & 2.054 & 3.3 & 10.7 & 29 & 53 & 44 & 33 \\
\hline 18 & Congok & DS & 16 & 1323 & 424 & 21.2 & 6.8 & 0.8 & 2.054 & 1.0 & 8.6 & 24 & 41 & 25 & 5 \\
\hline \multirow[t]{2}{*}{19} & Labong & DS & 16 & 1323 & 424 & 21.2 & 6.8 & 0.8 & 2.054 & 13.0 & 14.5 & 40 & 69 & 45 & 12 \\
\hline & PAHANG & & & & & & & & & & & & & & \\
\hline 20 & Chereh & RR & 1240 & 1139 & 310 & 1412.4 & 384.4 & 0.9 & 2.054 & 250.0 & 785.6 & 2152 & 56 & 1934 & -11 \\
\hline \multirow[t]{2}{*}{21} & Kelau /Langat & RR & 1950 & 997 & 200 & 1944.2 & 390.0 & 0.0 & \begin{tabular}{|l|}
2.054 \\
\end{tabular} & 137.0 & 942.9 & 2583 & 49 & 2420 & -7 \\
\hline & SARAWAK & & & & & & & & & & & & & & \\
\hline 22 & Sika & DS & 30 & 2384 & 442 & 71.5 & 13.3 & 0.3 & 2.054 & 3.2 & 34.1 & 93 & 48 & na & na \\
\hline 23 & Assyakirin & DS & 28 & 2384 & 442 & 66.8 & 12.4 & 0.3 & 2.054 & 33.7 & 52.0 & 142 & 78 & na & na \\
\hline 24 & Gerugu & RR & 77 & 1785 & 299 & 137.4 & 23.0 & 0.4 & 2.054 & 7.8 & 71.2 & 195 & 52 & 140 & -39 \\
\hline \multirow[t]{2}{*}{25} & Bengoh & RR & 633 & 2395 & 403 & 1516.0 & 255.1 & 0.5 & 2.054 & 137.0 & 858.2 & 2351 & 57 & 2094 & -12 \\
\hline & LABUAN & & & & & & & & & & & & & & \\
\hline 26 & Bukit Kuda & DS & 2 & 1759 & 553 & 3.5 & 1.1 & 0.2 & 2.054 & 4.7 & 2.8 & 8 & 80 & 8.5 & 10 \\
\hline 27 & Kerupang & DS & 0.5 & 1759 & 553 & 0.9 & 0.3 & 0.2 & 2.054 & 0.2 & 0.5 & 1 & 53 & 1.0 & -27 \\
\hline \multirow[t]{4}{*}{28} & Sg Pagar & DS & $\begin{array}{l}0.75 \\
\end{array}$ & 1759 & 553 & 1.3 & 0.4 & $\begin{array}{l}0.2 \\
\end{array}$ & \begin{tabular}{|l|}
2.054 \\
\end{tabular} & 0.4 & 0.8 & 2 & 60 & 1.5 & -44 \\
\hline & Dam & TYPE & Catchment & AAF & SD & AAF & SD & SKEW & 2 & Storage & Yield & Yield & Yield to AAF & WTP & Difference \\
\hline & & & \multicolumn{2}{|c|}{\begin{tabular}{|r|}
$\mathrm{km} 2 \mathrm{~mm} /$ year \\
\end{tabular}} & $\mathrm{mm} /$ year & MCM/year & MCM/year & nd & nd & \multicolumn{2}{|c|}{ MCM $/ \mathrm{MCM} /$ year } & Mld & $\%$ & Mld & $\%$ \\
\hline & & & MEAN & 1264 & $4 \quad 337$ & & 106 & 0.51 & & \multicolumn{2}{|c|}{55} & 610 & 55 & & \\
\hline \multicolumn{2}{|c|}{ DS Direct Supply } & & SD & 548 & 113 & & 150 & 0.45 & & \multicolumn{2}{|l|}{90} & 941 & 11 & & \\
\hline \multicolumn{2}{|c|}{ RR regulating reservoir } & & SKEW & 0.63 & 0.36 & & 1.41 & 0.99 & & 2.36 & & 1.62 & 0.20 & & \\
\hline & 54 50-year return per & & MIN & 388 & 143 & & 0.28 & 0.01 & & 0 & & 1 & 31 & & \\
\hline & & & MAX & 2395 & 553 & & 478 & 1.58 & & 370 & & 3023 & 80 & & \\
\hline & & & MEDIAN & 1232 & 306 & & 22 & 0.33 & & 24 & & 140 & 54 & & \\
\hline
\end{tabular}

The SYR model has included essentially five independent variables in the SYR regression equation. Out of five, standard deviation, skewness, and Z score appear to vary insignificantly as far as the data is concerned. To illustrate the significance of these independent variables, the other two variables, catchment area (which indirectly proportionate to reservoir inflows) and storage capacity were selected for comparison. Both catchment area and storage capacity are indeed positively correlated to the SYR yields with 
reasonable correlation coefficients. Both Figure 3 and 4 show significant positive correlations of SYR yields amongst their respective catchment areas (or inflow) and storage capacities.

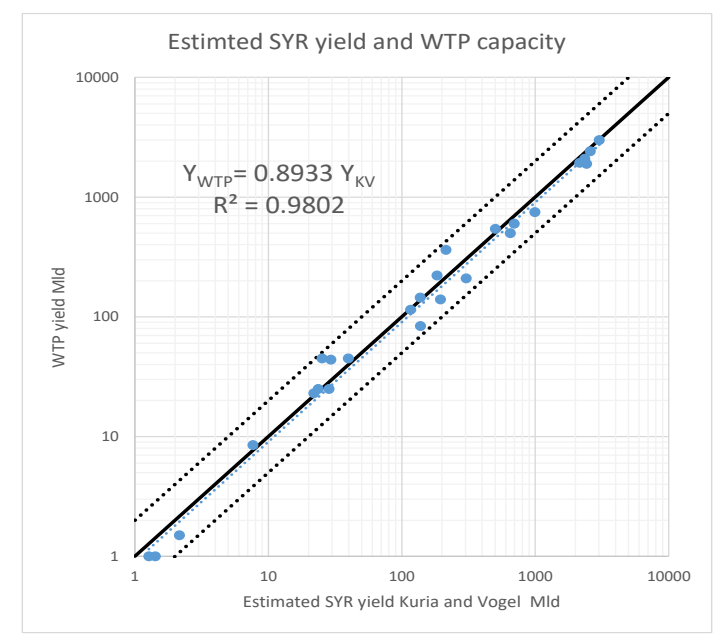

Figure 2. Comparison of SYR Yield by Kuria and Vogel (2014) and WTP Yield

$\mathrm{Y}_{\mathrm{KV}}=\mathrm{SYR}$ yield of Kuria and Vogel (2014) Mld

$\mathrm{Y}_{\mathrm{WTP}}=$ Water treatment plant (WTP) capacity, inclusive of known compensation flow Mld

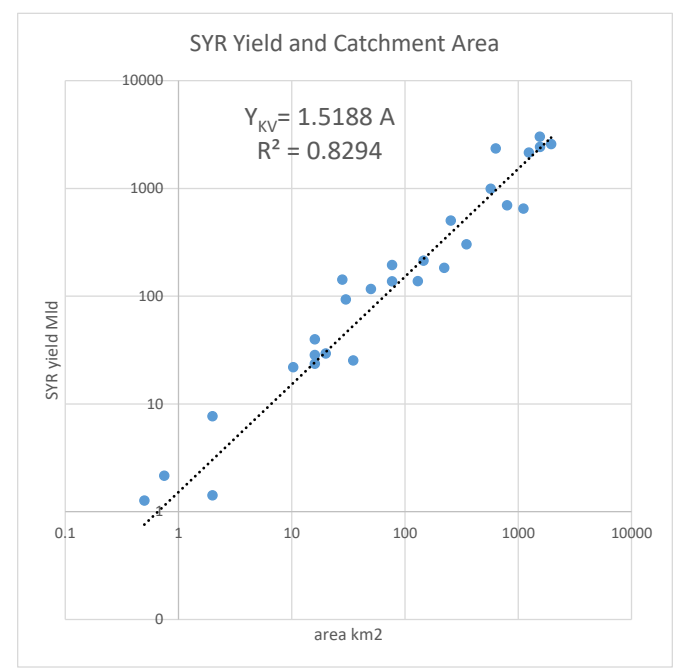


Figure 3. Comparison of SYR Yield by Kuria and Vogel (2014) and Catchment Area

$\mathrm{Y}_{\mathrm{KV}}=\mathrm{SYR}$ yield of Kuria and Vogel (2014) Mld

$\mathrm{A}=$ reservoir catchment area $\mathrm{km}^{2}$

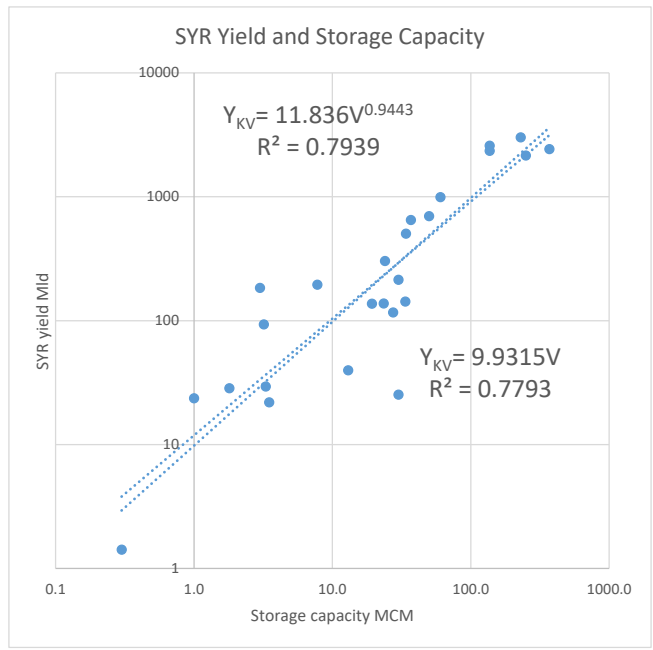

Figure 4. Comparison of SYR Yield by Kuria and Vogel (2014) and Storage Capacity

$\mathrm{Y}_{\mathrm{KV}}=\mathrm{SYR}$ yield of Kuria and Vogel (2014) Mld

$\mathrm{V}=$ reservoir storage capacity $\mathrm{MCM}$

\section{Conclusion}

This study undertakes an investigation on the applicability of SYR model (Kuria and Vogel, 2014) in Malaysia. The SYR model was originally developed on worldwide hydrometric database mainly from the United Kingdom, Australia, South Africa and the Europe continent. The model is a linearized regressed equation with five independent variables which represent the inflow statistical properties, reservoir capacity, and designated return period or probability of non-exceedance of low flow (as represented by the standard Z score of Normal distribution). 
Twenty-eight water supply reservoir schemes was selected for comparison in this study. From the water supply reservoir schemes, 17 and 11 reservoirs are operated under DS and RR mode respectively. The results of the SYR model by comparing the estimated yield to the known WTP capacity of these reservoir schemes were promisingly consistent and agreeable within a factor of two lines. Out of five variables, catchment area (indirectly proportionate to dam inflows) and storage capacity are positively correlated to the SYR yields.

Kuria and Vogel (2014) model did not explicitly take into account the amount of water loss due to evaporation from the lake surface area; as such this might in a way resulted in overestimation of the reliable yield by SYR model. However, it is possible that the losses due to evaporation might be insignificant especially during a spate of constant drawdown period when significant amount of releases were made. This begs for the alternative view that only a small quantity of waters will be lost by evaporation process due to the fast-shrinking lake surface area with respects to rapid reservoir water level drawdown. As such this only shows that the loss due to surface evaporation was negligible during this intervening period.

Another concern of the SRY screening model is the fact that the SYR yield estimation might not be applicable to the tropical Asia Pacific region as only a small fraction of database was originated from this region (i.e. only 58 out of the total 729 river basins adopted for calibration or in the process of derivation of the multiple nonlinear regression equation were from this region). Most of these databases were obtained from Australia, Continental Europe, and USA as reported by Kuria and Vogel (2014). For a country in the tropical climate region, such as Malaysia, there would be even fewer representative river basins adopted in the development and calibration of the SYR. Therefore, it would perhaps be shrouded with uncertainty if the SYR model utility can be extended with confidence to other region outside of the calibration domains. Nevertheless, comparison of the yield results of 28 reservoir schemes of DS and RR operational mode by SYR and WTP capacity showed promising outcome that the SYR model can be effectively applicable 
to Malaysia. Prior embarking into a more elaborated and detailed undertaking, it would be useful if SYR can be considered as a preliminary tool for yield estimation and/or comparison to existing water balance models as well.

The SYR model of Kuria and Vogel (2014) could provide a quick yield assessment for both DS and RR reservoir scheme. However, it appears that the methodology and underlying assumption of the model development are not suitable for PS mode of reservoir operation. In summary, the multivariate regression model SYR approach of Kuria and Vogel (2014) can be used as the first screening process of DS and RR operation mode reservoir yield estimation in Malaysia.

\section{References}

Baharudin SA, and FM Arshad. (2015). Water Management in the Paddy Area in

MADA. Economic \& Technol Management Review 10(a), 21-29.

Brandt, MJ, KM. Johnson, AJ. Elphinston, and DD. Ratnayaka. Twort's Water Supply. 7th edition, Elsevier, Netherland, (2016).

Chow VT. DR Maidment, and LW Mays (1988). Applied Hydrology. McGraw Hill,

New York. New York.

Ewing, J. and K. Domondon. (2016). Drought, Pollution and Johor's Growing Water

Needs. ISEAS Yusof Ishak Institute: Pespectives, 47, 1-10.

Heng HH, Pan WF, Siaw FL and Hii SP (2017a). Coastal and Estuary Reservoir: Case

Studies for Johor River Basin. J. Civil Eng. Sci and Technol. 8(1) 25-40.

Heng HH, Hii CP, Pan WF, and Siaw FL (2017b). Reservoir yield reassessment in

Selangor. Journal of Eng Technol. Application, in press.

JASA (2009). Sarawak Water Resources Management and Master Plan Study (SIWRMMP). State Planning Unit, Sarawak. 
Japan International Cooperation Agency (JICA) (1982). National Water Resources Study, Government of Malaysia

JPS (2011). National Water Resources Study (NWRS) Review 2000 to 2050.

Economic Planning Unit, Government of Malaysia.

Kuria, F.W. and R.M. Vogel (2014). A global water supply yield model with uncertainty analysis. Environmental Research Letter 9, Iopscience.iop.org. McMahon, TA and AJ Adeloye (2005). Water resources yield, first edition, Water

Resources Publication, Littleton, CO, USA.

McMahon, TA, GGS Pegram, RM Vogel, and MC Peel (2007). Review of Gould

Dincer Reservoir Storage-Yield-Reliability Estimates. Advances in Water Resources,

30, pp 1873-1882.

McMahon, TA and RG Mein (1986) River and reservoir Yield. Water Resources

Publication, Littleton, CO. USA.

Nagy I, K. Asante-Duah and I Zsuffa (2002) Hydrological dimensioning and operation of reservoir. Springer, Dordrecht, Federal Republic of Germany.

Shahabudin, SM (2015). Exploring the viability of dams is key to Malaysia water

resources development of the future. IEM Journal, 76(1) 1-23.

WMO (2008a). Guide to Hydrological Practices. Vol 1 Hydrology: From

Measurement to Hydrological Information. WMO No. 168. Worth Meteorological

Organization, Geneva, The Switzerland.

WMO (2008b). Guide to Hydrological Practices. Vol 2 Management of Water Resources and Application of Hydrological Practices. WMO No. 168. Worth Meteorological Organization, Geneva, The Switzerland. 